\title{
PEMANTAUAN KUALITAS AIR SUMUR MENGGUNAKAN MULTIPROBE SENSOR DIGITAL DI WILAYAH SEKITAR SEMBURAN LUMPUR SIDOARJO
}

\author{
Oleh : Heru Dwi Wahjono \\ Pusat Teknologi Lingkungan, BPPT
}

\begin{abstract}
Bursts of mud in Sidoarjo has caused changes in environmental quality around the bursts area. Observation in that area indicate there have been changes in air quality and odor caused by mud spurt. In addition, changes in the geological structure of land in the area around the mud spurt, has resulted some water spurt phenomenon that came from the well pump belong to some residensts in that area. This water spurt phenomenon is followed by the change of water quality which was to be used for the needs of daily living, now in some villages in the area around the mud bursts can no longer be used. To find out some parameters of water quality that arises from the some well pumps that produce big water spurt, we need to performed water quality monitoring using multiprobe digital sensors that are able to measure several parameters at once. This paper presents the measurement data of water quality in some well pumps that produce big water spurts with the YSI600R digital sensor.
\end{abstract}

Keywords : Perubahan kualitas lingkungan, semburan lumpur Sidoarjo, pemantuan kualitas air, sumber bubble, sumur pompa, sumur bor, separasi air dan gas, multi probe digital sensor

\section{PENDAHULUAN}

\subsection{Latar Belakang}

Bencana semburan lumpur di Sidoarjo yang telah terjadi sejak tahun 2006 silam telah banyak memberikan dampak negatif terhadap kehidupan masyarakat di sekitarnya. Selain merusak infrastruktur yang ada di wilayah tersebut, semburan lumpur juga mengakibatkan terjadinya kerusakan lingkungan mulai dari kerusakan lahan, perubahan struktur geologi bawah tanah, pencemaran udara akibat gas yang keluar bersama semburan lumpur dan perubahan kualitas air dari sumber-sumber air yang berasal dari sumur bor.

Penduduk yang semula bisa menikmati sumber air dari sumur pompa dengan kualitas yang baik, kini tidak lagi dapat digunakan. Hal ini selain dikarenakan air sumur yang menyembur dengan debit yang fluktuatif, juga disebabkan kualitas air sumur yang berubah, sehingga mendorong pemerintah daerah setempat untuk menyediakan air bersih bagi kebutuhan air bersih penduduk di kawasan sekitar semburan lumpur. Foto berikut ini adalah bantuan pemerintah daerah menyediakan prasarana air bersih bagi masyarakat di sekitar semburan lumpur.

Walaupun air sumur pompa yang dimiliki penduduk memiliki debit yang bertambah, namun karena sudah berubah kualitasnya, saat ini masyarakat di sekitar wilayah semburan lumpur sangat bergantung pada suplai air bersih yang disediakan oleh pemerintah daerah setempat untuk memenuhi kebutuhan air bersihnya. ${ }^{1)}$

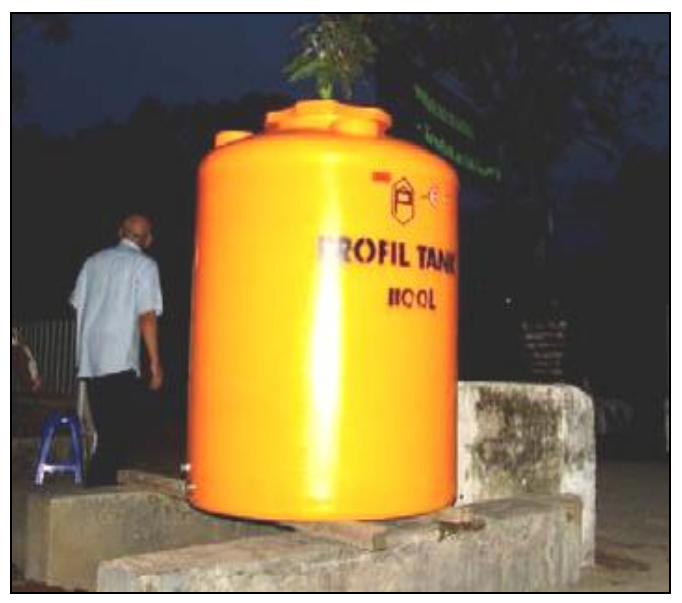

Gambar 1. Bantuan Tangki Air Bersih 1)

Walapun air yang keluar dari sumur pompa penduduk berwarna jernih dan keluar dengan debit yang bertambah besar, namun air tersebut pada intinya sudah tercemar. Agar air sumur pompa yang sudah tercemar ini dapat dimanfaatkan kembali dengan aman oleh penduduk, maka perlu diketahui kualitas airnya, sehingga selanjutnya dapat ditentukan teknologi pengolahan air yang tepat. Selain itu hasil pemantuan kualtias airnya diharapkan dapat memberikan informasi yang jelas mengenai kondisi air sumur penduduk dengan tepat. 


\subsection{Tujuan Dan Sasaran}

Tujuan dari kegiatan pemantauan ini adalah untuk mendapatkan data kualitas air di beberapa sumur bor / pompa yang dimiliki oleh penduduk di sekitar wilayah semburan lumpur. Sedangkan sasarannya adalah mengetahui pengaruh semburan lumpur terhadap perubahan kualitas air sumur pompa penduduk.

\subsection{Metodologi}

Metodologi yang digunakan untuk melaksanakan kegiatan survei pemantauan kualitas air adalah sebagai berikut:

a. Studi literatur, dilakukan dengan menggali informasi dan literatur mengenai hasil analisa kualitas air lumpur dan air sumur penduduk di sekitar wilayah semburan lumpur yang telah dilakukan oleh instansi lain.

b. Penentuan lokasi survei, dilakukan dengan memilih lokasi pemantauan yang didasarkan pada data hasil studi literatur dan kondisi eksisting pada saat itu.

c. Persiapan peralatan, dilakukan dengan mempersiapkan peralatan sensor kualtias air yang telah dimiliki oleh Pusat Teknologi Lingkungan, BPPT. Persiapan dilakukan untuk pengukuran secara mobile yang dapat berpindah-pindah dari satu lokasi pengamatan ke lokasi pengamatan lain.

d. Survei lapangan, dilakukan dengan mengunjungi lokasi survei yang telah ditentukan. Peralatan sensor kualitas air dicelupkan langsung ke dalam sumur penduduk jika kondisi memungkinkan. Jika kondisi tidak memungkinkan, maka air yang berasal dari sumur pompa diambil terlebih dahulu dan ditempatkan dalam suatu wadah sehingga sensor kualtias air dapat dicelupkan.

e. Pencatatan data dan pelaporan, dilakukan dengan merekam data secara langsung ke dalam memori sensor dan membuat salinan rekaman data melalui perangkat komputer notebook. Data yang telah terekam kemudian dimasukkan ke dalam tabel sesuai lokasi pemantauan.

\subsection{Lokasi Survei}

Dari hasil studi literatur dan data yang telah dikumpulkan oleh Badan Penanggulangan Lumpur Sidoarjo / BPLS sebagai instansi yang mengkoordinir di lapangan, diketahui bahwa fenomena perubahan kualitas air di sumur penduduk banyak terjadi di bagian barat tanggul lumpur ${ }^{1)}$. Oleh karena itu lokasi survei ditentukan di bagian barat tanggul lumpur yang berada di desa Siring Barat.

Ada beberapa titik lokasi yang diamati, namun dalam tulisan ini hanya dibahas empat titik lokasi survei yang memiliki sumur pompa dengan kategori sebagai sumber bubble besar. Yang dimaksud dengan sumur dengan kategori sebagai sumber bubble besar adalah sumur pompa yang memiliki semburan air dengan debit besar dan diikuti oleh semburan gas yang keluar bersama-sama semburan air ${ }^{2}$. Gambar di bawah ini adalah sumur pompa yang menyemburkan air dengan debit yang besar.
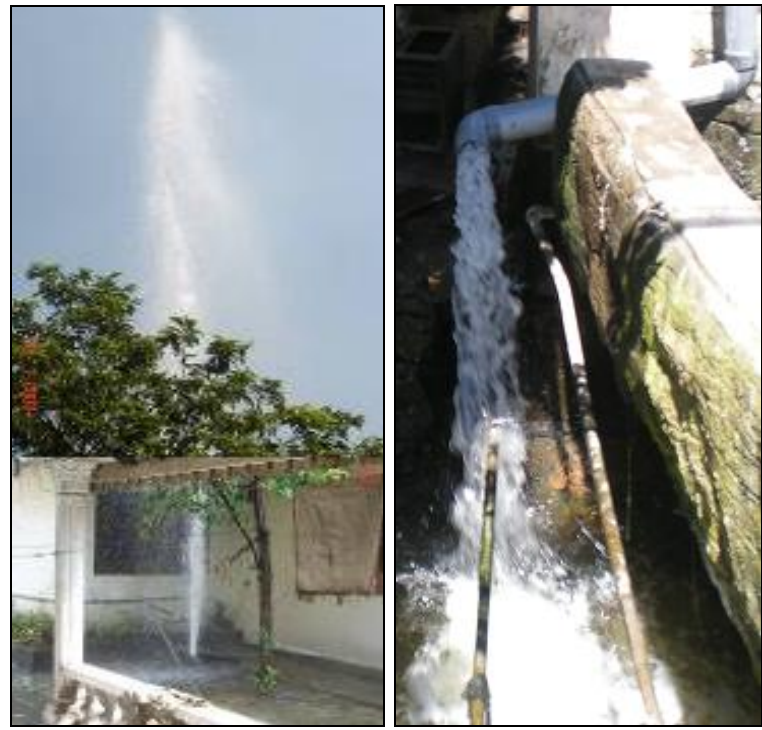

Gambar 2. Sumur Dengan Kategori Sebagai Sumber Bubble Besar ${ }^{2}$

Keempat lokasi survei yang telah dipilih seperti pada gambar 3 peta lokasi survei adalah sebagai berikut :

(1). Koord. (70 31' 21,4", $112^{\circ} 42^{\prime}$ 08,8') : Pabrik Es $\pm 200 \mathrm{~m}$ dari tanggul. Sumber bubble berasal dari sumur pompa kedalaman $\pm>50$ $\mathrm{m}$. Semburan gas dan air belum dipisahkan.

(2). Koord. (7० 31' 30,8”, $112 \circ 42^{\prime}$ 13,3") : Bengkel kendaraan di samping Wartel di pinggir jalan $\pm 50 \mathrm{~m}$ dari tanggul. Semburan gas dan air sudah dipisahkan.

(3). Koord. (7० 31' 33,9”, $112^{\circ} 42^{\prime}$ 58,9") : Wartel di pinggir jalan $\pm 50 \mathrm{~m}$ dari tanggul. Sumber bubble berasal dari sumur pompa kedalaman $\pm 40 \mathrm{~m}$. Semburan gas dan air sudah dipisahkan.

(4). Koord. (70 31' 31,7', $\left.112^{\circ} 42^{\prime} 13,3^{\prime \prime}\right)$ : Rumah Bp Ahyat RT3/1, $\pm 70 \mathrm{~m}$ dari tanggul. Sumber bubble berasal dari sumur pompa kedalaman $+40 \mathrm{~m}$. Semburan gas dan air sudah dipisahkan. 


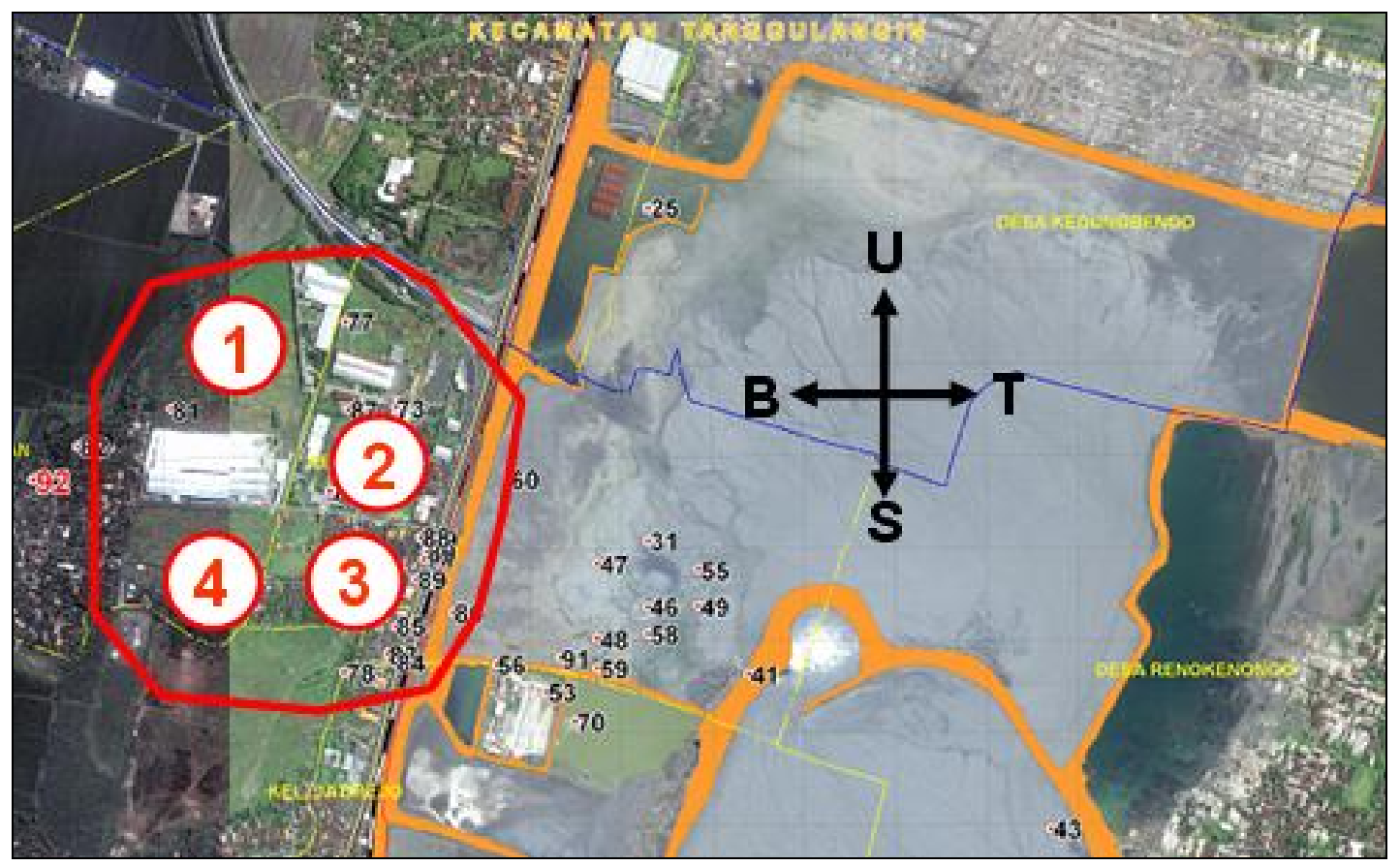

Gambar 3. Peta Lokasi Survei ${ }^{2)}$

\subsection{Peralatan Survei}

Beberapa peralatan utama dan peralatan penunjang yang digunakan untuk survei pengukuran kualitas air sumur adalah sebagai berikut :

a. Sensor digital kualitas air yang mampu mengukur 6 parameter kualitas air, yaitu Suhu, TDS, Salinitas, DO, pH, dan Conductifity.

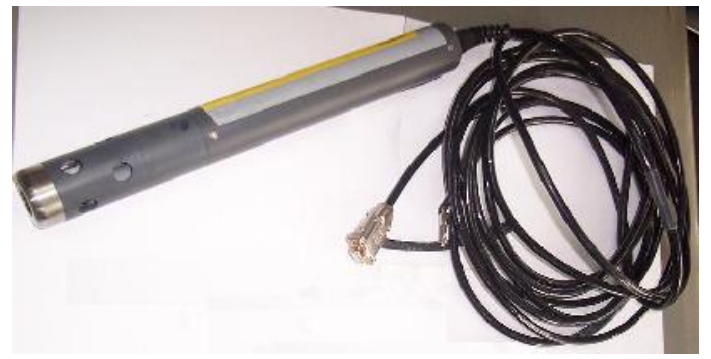

Gambar 4. Sensor Digital ${ }^{3)}$

b. Kabel serial - USB untuk mengkonversikan notebook yang tidak memiliki sambungan komunikasi serial berikut software drivernya.

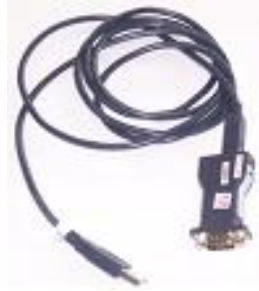

Gambar 5. Kabel Komunikasi Serial-USB 3) c. Notebook yang memiliki sambungan komunikasi serial RS232C atau USB.

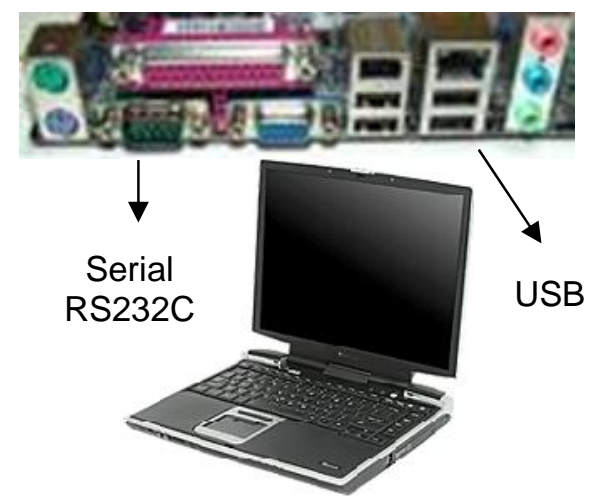

Gambar 6. Notebook Dengan Konektor Serial RS232C atau USB ${ }^{3)}$

d. Software terminal emulator seperti kermit atau hyperterminal untuk mengoperasikan sensor kualitas air.

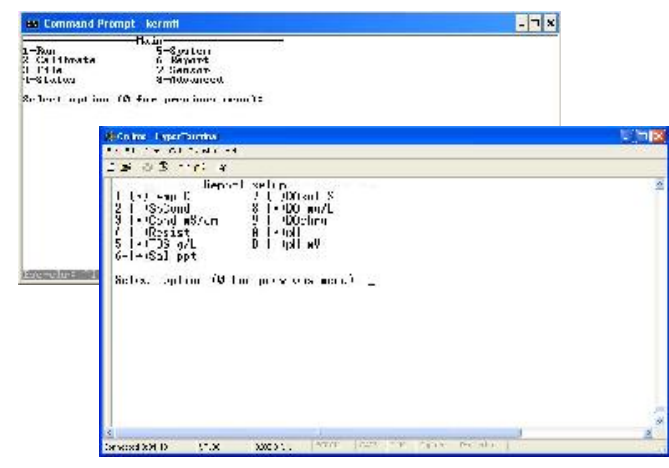

Gambar 7. Software Terminal Emulator ${ }^{3)}$ 
e. GPS untuk menentukan lokasi koordinat survei di lapangan.

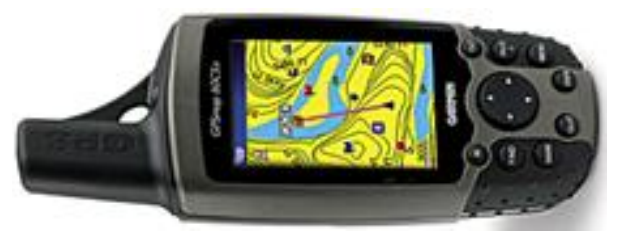

Gambar 8. GPS Untuk Penentuan Koordinat

f. Car DC 12V - AC 220V converter yang dapat mengubah tegangan DC 12 Volt menjadi AC 220 Volt untuk mensuplai listrik untuk peralatan survei menggunakan sumber listrik dari kendaraan operasional.

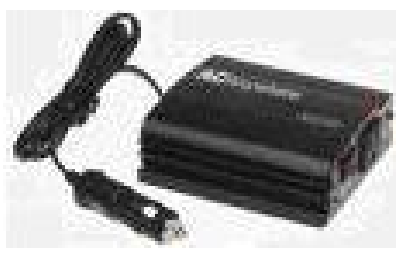

Gambar 9. Car DC-AC Converter

\section{PEMBAHASAN}

Semburan lumpur di Sidoarjo telah mengakibatkan terjadinya perubahan kondisi lingkungan, sehingga mempengaruhi kualitas hidup masyarakat di sekitar wilayah terdampak. Beberapa perubahan kondisi lingkungan yang mempengaruhi daerah terdampak, antara lain :

1. Penurunan tanah yang terjadi akibat dari semburan lumpur yang terus menerus, dapat berpengaruh langsung terhadap kekuatan tanggul, maupun akses transportasi material untuk penambahan, perluasan dan perkuatan tanggul.

2. Keluarnya gas dari sumber bubble gas yang semakin banyak baik dalam ukuran besar maupun kecil pada daerah yang tidak masuk dalam zona daerah terdampak.

3. Keluarnya semburan air dengan debit yang besar dari beberapa sumur pompa penduduk yang memiliki kedalaman 40-70 m dengan kualitas air yang semakin buruk.

4. Keluarnya gas bersamaan dengan semburan air dari beberapa sumur pompa di rumahrumah penduduk.

5. Kualitas udara ambien yang buruk akibat terciumnya bau gas yang keluar baik yang berawal dari dalam tanggul lumur yang terbawa oleh angin, maupun bau gas yang keluar bersamaan semburan air.

Perubahan kondisi kualitas air sumur yang berada di sekitar wilyah semburan lumpur sangat dipengaruhi oleh kualitas lumpur yang keluar dari dalam tanggul. Beberapa hipotesa yang ada mengenai perubahan kualitas air sumur pompa penduduk antara lain :

- Air sumur pompa yang keluar memancar disebabkan oleh tekanan struktur geologi tanah di dalam tanggul yang terus menerus menekan aquifer sehingga air dan gas yang berada di dalam tanah tertekan dan muncul ke permukaan melalui sumur dalam (sumur pompa ) penduduk.

- Air yang keluar dari sumur dalam berasal dari aquifer tanah dalam, sehingga memiliki kualitas air yang berbeda dengan kualitas air lumpur dari dalam tanggul.

- Air yang berada di dalam sumur gali (sumur dangkal) berasal dari sumber yang sama dengan air lumpur dari dalam tanggul, sehingga memiliki kualias air yang sama.

Untuk membuktikan beberapa hipotesa di atas, perlu dilakukan survei pengamatan terhadap kualtias air sumur pompa penduduk. Dari data hasil analisa kualitas air sumur pompa tersebut akan dapat disimpulkan apakah kualitas airnya sama dengan kualitas air lumpur dari dalam tanggul atau tidak dan sekaligus dapat menjawab apakah air yang keluar dari dalam sumur pompa penduduk adalah air yang sama dengan air yang berada dari dalam tanggul atau tidak.

\subsection{Pemisahan Air dan Gas}

Untuk mengurangi konsenstrasi gas di permukaan guna mencegah terjadinya bencana atau kecelakan yang lebih parah, perlu dilakukan pemisahan antara air dan gas yang keluar dari sumur pompa penduduk. Tim teknis BPLS telah memberikan panduan dan contoh teknis untuk memisahkan air dan gas yang keluar dari dalam sumur pompa. Pada prinsipnya air yang keluar dalam jumlah debit yang besar akan dialirkan ke saluran drainase, sedangkan gas yang turut keluar akan disalurkan melalui pipa PVC untuk dibuang ke udara.

Gambar 10 adalah gambar rancangan pemisah air dan gas yang dapat dibuat menggunakan drum bekas dan pipa PVC 4" serta contoh aplikasinya di salah satu sumur pompa di rumah penduduk. Pengecoran dengan semen beton dapat dilakukan untuk memperkuat posisi peletakan drumnya agar tidak mudah lepas disebabkan tekanan semburan air yang besar. Pipa PVC untuk pembuangan gas ke udara juga harus diikat dengan tiang atau dengan benda lain di dekatnya sedemikian rupa agar tidak mudah bergerak ke sana kemari. Air yang keluar melalui pembuangan kemudian disalurkan ke saluran drainase atau sungai yang ada. 

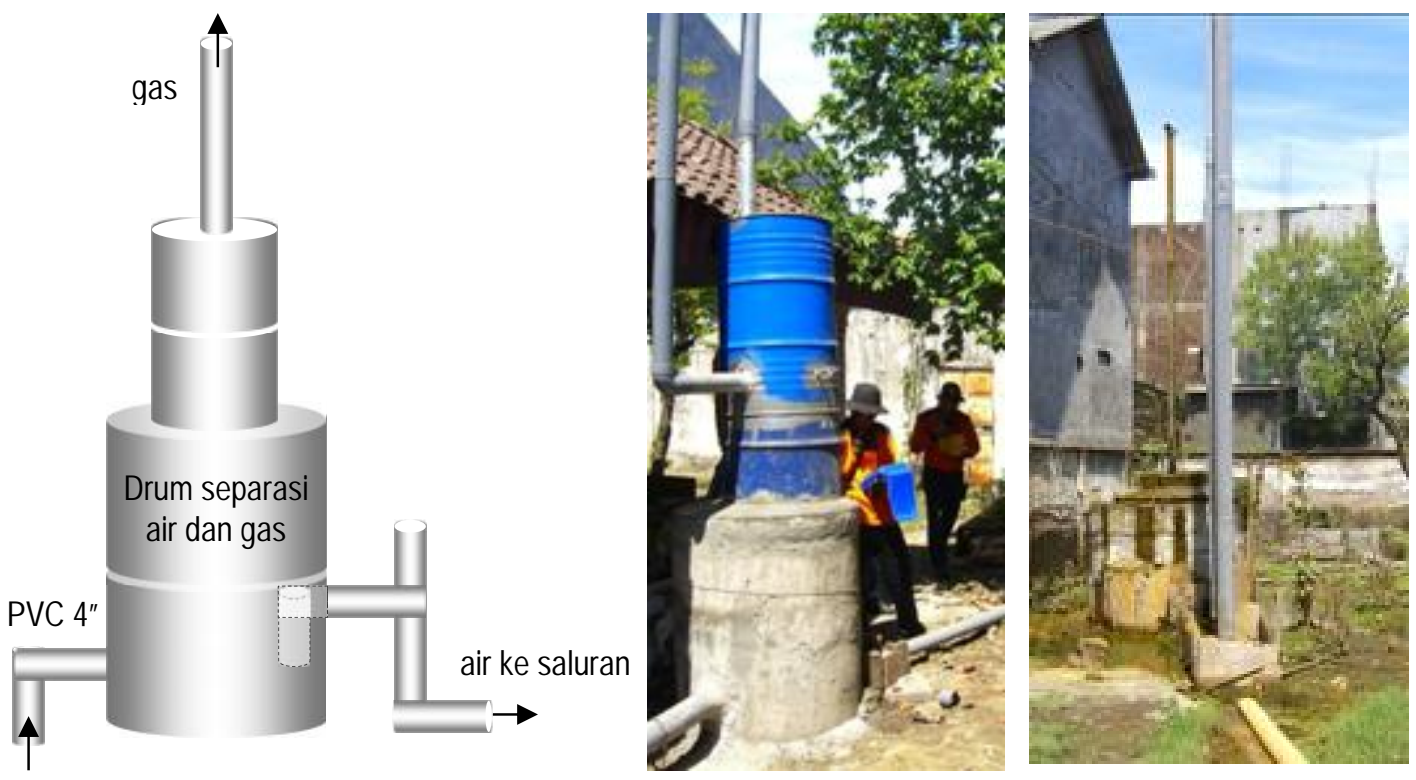

Semburan air dan gas

Gambar 10. Rancangan dan Contoh Aplikasi Drum Separasi Air dan Gas 2)

Sistim separasi air dan gas seperti pada gambar di atas sudah cukup efektif untuk memisahkan air dan gas serta mengurangi konsentrasi gas methan di permukaan sehingga meminimalkan terjadinya kebakaran yang dapat membahayakan penduduk di sekitarnya.

\subsection{Pengukuran Kualitas Air Dengan Sensor YSI600R}

Sensor YSI600R merupakan sensor digital yang dapat digunakan untuk mengukur kualitas air untuk paramater-parameter sebagai berikut : ${ }^{5}$

- Temperatur dalam satuan $\left[{ }^{\circ} \mathrm{C}\right]$

- Conductivity atau DHL (Daya Hantar Listrik) dalam satuan $[\mathrm{mS} / \mathrm{cm}]$

- TDS (Total Dissolved Substance) atau jumlah zat padat terlarut dalam satuan $[\mathrm{g} / \mathrm{l}]$

- Salinity / salinitas / kadar garam dalam air dengan satuan [ppt]

- DO (Dissovled Oxygen) atau jumlah oksigen dalam air dengan satuan [mg/l]

- $\mathrm{pH}$ untuk mengukur kondisi asam/basa.

Sebelum digunakan untuk pengukuran dilakukan kalibrasi terhadap masing-masing probe senseor.

Sensor digital YSI600R dioperasikan menggunakan laptop yang memiliki konektor serial komunikasi RS232C. Walaupun saat ini kebanyakan laptop tidak dilengkapi konektor serial komunikasi RS232C, namun konektor USB yang ada tetap dapat digunakan, yakni dengan memanfaatkan kabel konverter USB-RS232C dibantu dengan software driver untuk kabel konverter tersebut. Gambar berikut adalah cara penyambungan sensor YSI600R dengan laptop.

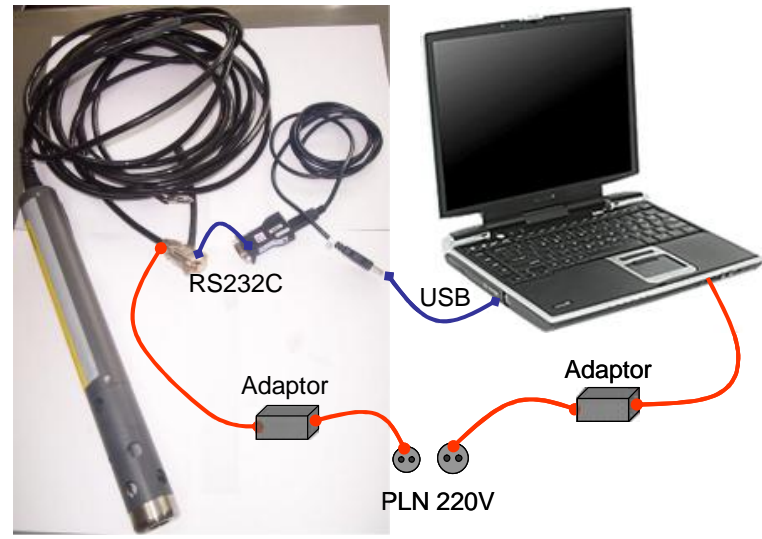

Gambar 11. Koneksi Kabel Sensor YSI600R ke Laptop Menggunakan Konverter RS232C-USB

Pengoperasian sensor digital dilakukan dengan menggunakan aplikasi perangkat lunak hyperterminal yang sudah ada dalam sistem operasi MS Windows 98/2000/XP/Vista. Jika menggunakan sistem operasi lain seperti DOS atau Unix Open Source, misalnya Linux $/{ }^{*} B S D$ dapat digunakan aplikasi Kermit yang dapat diunduh dari internet.

Yang perlu diperhatikan dalam pengoperasiannya adalah format protokol komunikasi yang digunakan, yakni : ${ }^{3}$

- Port komunikasi COM1/COM2/COM\# yang disesuaikan dengan koneksi yang ada.

- Kecepatan komunikasi (Baud Rate) dipilih 9600 bits per second

- Panjang data per paket data : 8 bits

- Parity check : none

- Stop bits : 1

- Flow Control : none 
Jika protokol komunikasi sudah diset dan koneksi sudah diaktifkan, maka hyperterminal akan menampilkan command prompt '\#' pada layar monitor. Di depan prompt ini dapat diketikkan perintah membaca data, yaitu 'DATA' atau menampilkan menu utama firmware sensor digital, yaitu 'MENU'. Melaui menu firmware yang perlu ditentukan adalah :

- Data informasi tanggal dan jam.

- Data interval pengukuran dalam satuan detik.

- Data nama/nomor identitas lokasi sampling.

- Data parameter ukur berikut satuannya.

- Nama file untuk menyimpan data.

Setelah setting firmware di atas selesai, selanjutnya dilakukan pengukuran data selama beberapa menit untuk mendapatkan beberapa record data di setiap titik pengamatan. Data dapat disimpan ke dalam file yang berbeda untuk mempermudah penyimpanan data.

\subsection{Hasil Survei Pengukuran Kualitas Air Sumur Dalam}

Pemilihan lokasi survei adalah lokasi sumur pompa (sumur dalam) dengan kategori kategori besar yang berada di sekitar pemukiman warga desa Siring Barat. Lokasi yang dipilih merupakan lokasi yang telah diidentifikasi oleh tim gas BPLS dan telah dibuatkan sistem pemisah antara air dan gas.

Pada umumnya lokasi sumur pompa dengan semburan gas dan air yang besar berasal dari sumur pompa milik warga dengan kedalaman sekitar 40 70m. Jarak antara lokasi sumur pompa yang diamati dengan sisi barat tanggul lumpur kurang lebih 100 - 700 meter.

Hasil pengukuran kondisi kualitas air di lokasi-lokasi sumur pompa tersebut adalah sebagai berikut :

1. Nama Lokasi : Pabrik Es, Koordinat Lokasi : $7^{\circ} 31^{\prime} 21,4^{\prime \prime}$ LS dan $112^{\circ} 42^{\prime}$ 8,8” BT, Elevasi : $27 \mathrm{~m}$, Lokasi Sumur : yang berada di depan pabrik (Sumur 1) dengan kedalaman $\pm 40 \mathrm{~m}$ dan yang berada di belakang pabrik (Sumur2) dengan kedalaman $\pm 30 \mathrm{~m}$.

Tabel 1. Hasil Pengukuran Kualitas Air Sumur di Pabrik Es

\begin{tabular}{|l|c|c|c|c|c|}
\hline \multirow{2}{*}{$\begin{array}{l}\text { LOKASI } \\
\text { SUMUR }\end{array}$} & \multicolumn{5}{|c|}{ DATA PENGUKURAN } \\
\cline { 2 - 6 } & $\begin{array}{c}\text { TEMP } \\
\text { (oC) }\end{array}$ & $\begin{array}{c}\text { COND } \\
\text { (mS/cm) }\end{array}$ & $\begin{array}{c}\text { TDS } \\
\text { (g/l) }\end{array}$ & $\begin{array}{c}\text { SAL } \\
\text { (ppt) }\end{array}$ & pH \\
\hline Sumur 1 & 30,7 & 1,345 & 0,88 & 0,6 & 6,03 \\
\hline Sumur 2 & 30,2 & 1,572 & 0,93 & 0,7 & 7,40 \\
\hline
\end{tabular}

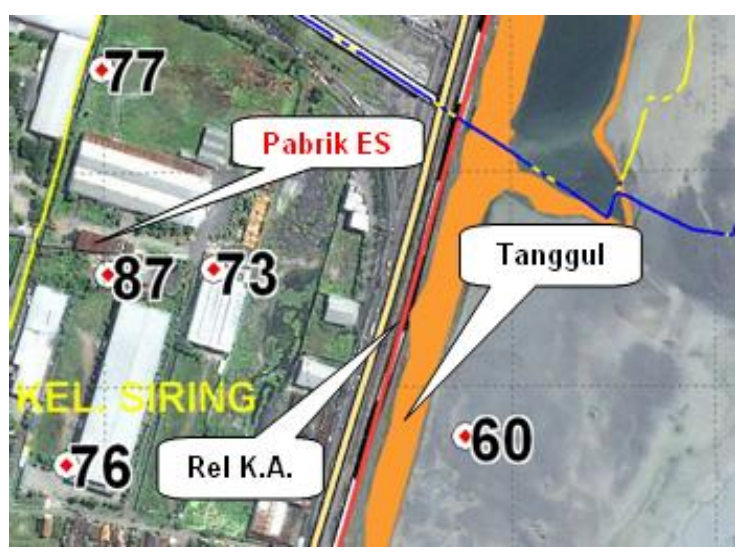

Gambar 12. Lokasi Survei di Pabrik ES (Titik 87)

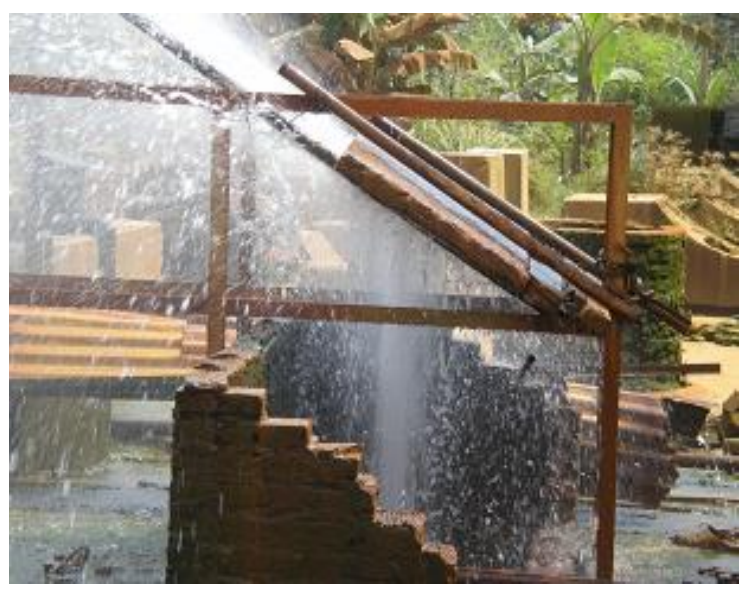

Gambar 13. Foto Sumur 2 di Pabrik ES

2. Nama Lokasi : Bengkel Kendaraan, Koordinat Lokasi : $7^{\circ} 31^{\prime}$ 30,8" LS dan $112^{\circ}$ 42' 13,3" BT, Elevasi : 23 m, Lokasi Sumur : yang berada di tangah kosong sebelah bengkel (Sumur 1) dengan kedalaman $\pm 30 \sim$ $40 \mathrm{~m}$ dan yang berada di dalam bengkel (Sumur2) dengan kedalaman $\pm 30 \sim 40 \mathrm{~m}$.

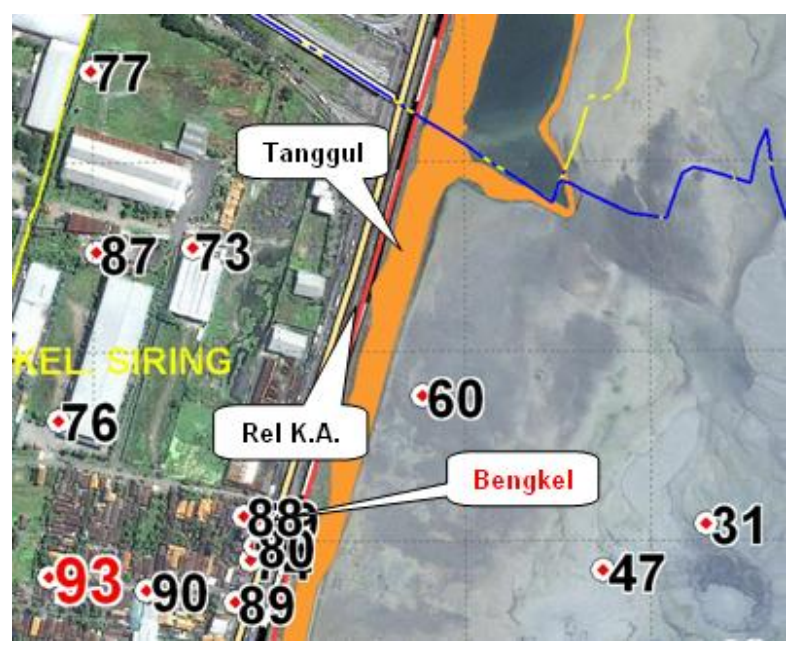

Gambar 14. Lokasi Survei di Bengkel Kendaran (Titik 88) 


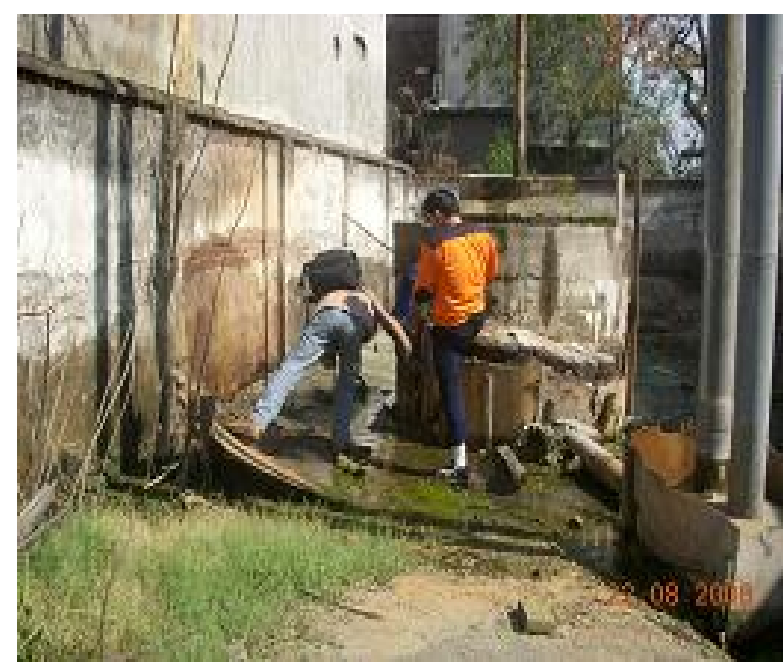

Gambar 15. Sumur 1 di Sebelah Bengkel

Tabel 2.Hasil Pengukuran Kualitas Air Sumur di Bengkel Kendaraan

\begin{tabular}{|l|c|c|c|c|c|}
\hline LOKASI & \multicolumn{5}{|c|}{ DATA PENGUKURAN } \\
\hline SUMUR & $\begin{array}{c}\text { TEMP } \\
\text { (oC) }\end{array}$ & $\begin{array}{c}\text { COND } \\
\text { (mS/cm) }\end{array}$ & $\begin{array}{c}\text { TDS } \\
\text { (g/l) }\end{array}$ & $\begin{array}{c}\text { SAL } \\
\text { (ppt) }\end{array}$ & pH \\
\hline Sumur 1 & 30,8 & 1,742 & 1,02 & 0,78 & 5,8 \\
\hline Sumur 2 & 30,7 & 1,372 & 0,80 & 0,61 & 5,9 \\
\hline
\end{tabular}

3. Nama Lokasi : Wartel, Koordinat Lokasi : $7^{\circ}$ 31' 33,9" LS dan $112^{\circ} 42^{\prime}$ 58,9" BT, Elevasi : $23 \mathrm{~m}$, Lokasi Sumur : bukan berasal dari sumur bor (kedalaman $\pm 40 \mathrm{~m}$ ) yang ada, tapi berasal dari rekahan tanah di dekat sumur bor di dalam ruangan wartel. Air yang keluar dari rekahan tersebut cukup besar. Sedangkan sumur bor yang ada menurut pemiliknya tidak terdapat fenomena apa-apa.

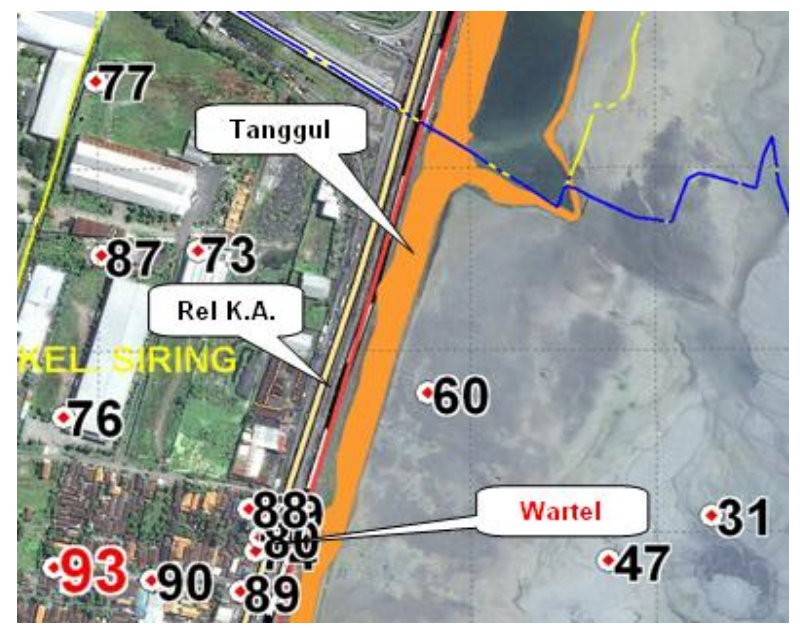

Gambar 16. Peta Lokasi Survei di Wartel (Titik 80)

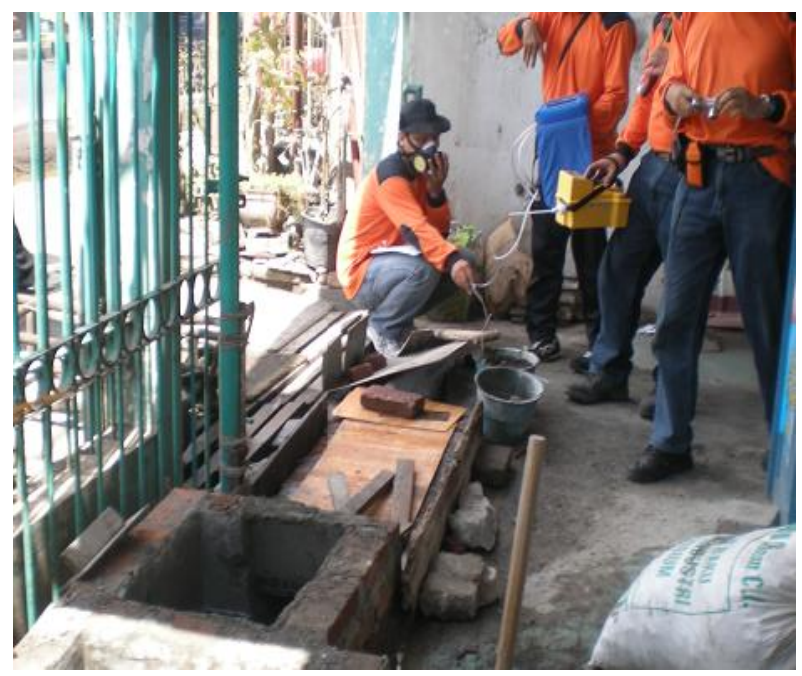

Gambar 17. Foto Sumber Air di Wartel

Tabel 3. Hasil Pengukuran Kualitas Air di Wartel

\begin{tabular}{|c|c|c|c|c|c|}
\hline \multirow{2}{*}{$\begin{array}{c}\text { LOKASI } \\
\text { SUMUR }\end{array}$} & \multicolumn{5}{|c|}{ DATA PENGUKURAN } \\
\cline { 2 - 7 } & $\begin{array}{c}\text { TEMP } \\
\text { (oC) }\end{array}$ & $\begin{array}{c}\text { COND } \\
\text { (mS/cm) }\end{array}$ & $\begin{array}{c}\text { TDS } \\
\text { (g/l) }\end{array}$ & $\begin{array}{c}\text { SAL } \\
\text { (ppt) }\end{array}$ & pH \\
\hline Wartel & 30,8 & 8,632 & 5,04 & 4,25 & 5,8 \\
\hline
\end{tabular}

4. Nama Lokasi : Warung di Rumah Ibu Purwaningsih, Koordinat Lokasi : $7^{\circ} 31$ ' 33,3" LS dan 112 ${ }^{\circ} 42^{\prime} 11,8^{\prime \prime}$ BT, Elevasi : 22 m, Lokasi Sumur : berada di dalam rumah di dekat dapur dengan kedalaman $\pm 40 \mathrm{~m}$. Debit air yang keluar dari sumur cukup besar.

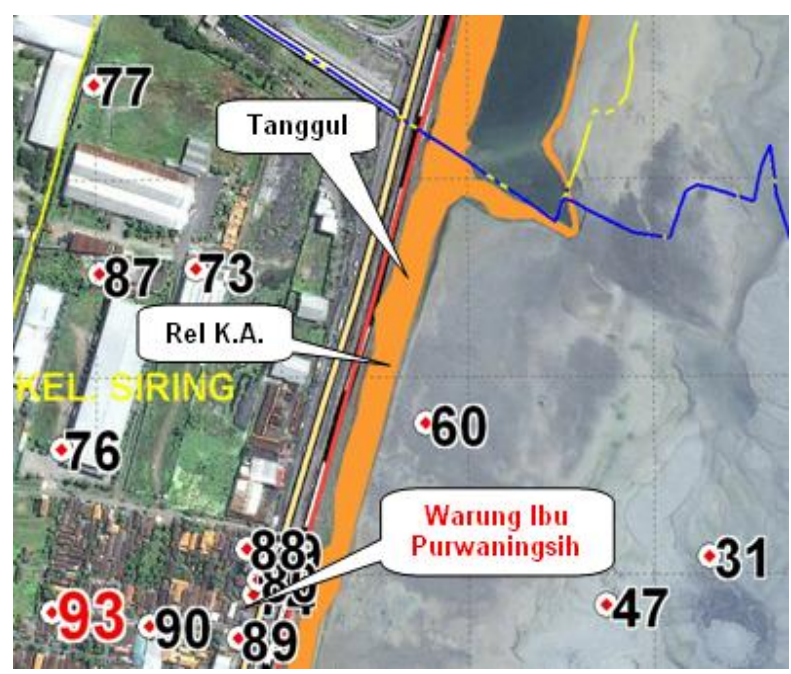

Gambar 18. Peta Lokasi Survei di Warung Ibu Purwaningsih (Titik 74)

Tabel 4. Hasil Pengukuran Kualitas Air Sumur di Warung lbu Purwaningsih 


\begin{tabular}{|l|l|l|l|l|l|}
\hline \multirow{2}{*}{$\begin{array}{l}\text { LOKASI } \\
\text { SUMUR }\end{array}$} & \multicolumn{4}{|l|}{ DATA PENGUKURAN } \\
\cline { 2 - 7 } & $\begin{array}{l}\text { TEMP } \\
\text { (oC) }\end{array}$ & $\begin{array}{l}\text { COND } \\
\text { (mS/cm) }\end{array}$ & $\begin{array}{l}\text { TDS } \\
\text { (g/l) }\end{array}$ & $\begin{array}{l}\text { SAL } \\
\text { (ppt) }\end{array}$ & pH \\
\hline $\begin{array}{l}\text { Warung Ibu } \\
\text { Purwaningsih }\end{array}$ & 31,3 & 1,304 & 0,76 & 0,57 & 6,24 \\
\hline
\end{tabular}

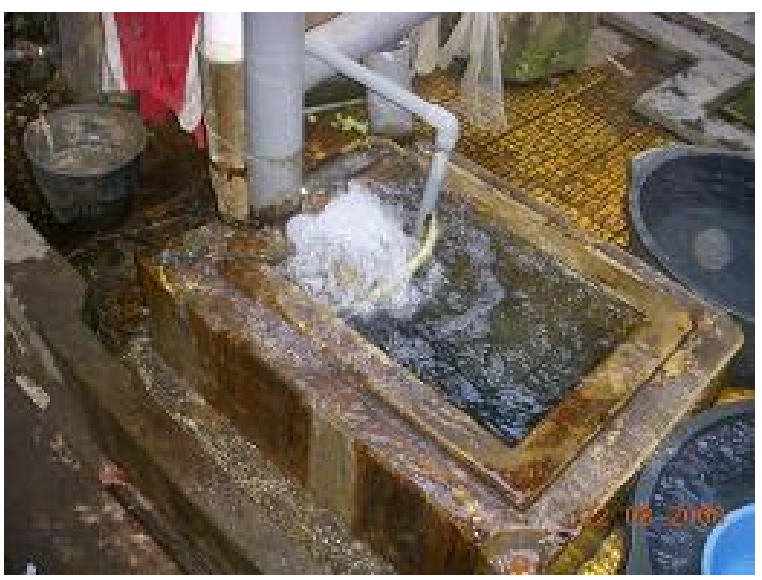

Gambar 19. Foto Air Yang Keluar Dari Sumur di Warung lbu Purwaningsih

\subsection{Hasil Survei Pengukuran Kualitas Air Sumur Dangkal}

Survei terhadap kualitas air sumur dangkal di wilayah barat tanggul telah dilakukan oleh BPLS sejak awal terjadinya semburan lumpur. Dari hasil survei pengukuran kualitas air, diperoleh data kualitas air sumur dangkal yang semakin menurun. Beberapa parameter penting khususnya TDS menunjukkan angka yang semakin meningkat walaupun secara visual air masih terlihat bersih. Gambar 20-23 berikut menunjukkan grafik kualitas air untuk konsentrasi parameter TDS di empat sumur dangkal yang terletak tersebar di sebelah barat tanggul, yakni : Desa Siring, Desa Jatirejo, Desa Pamotan dan Desa Ketapang ${ }^{4)}$.

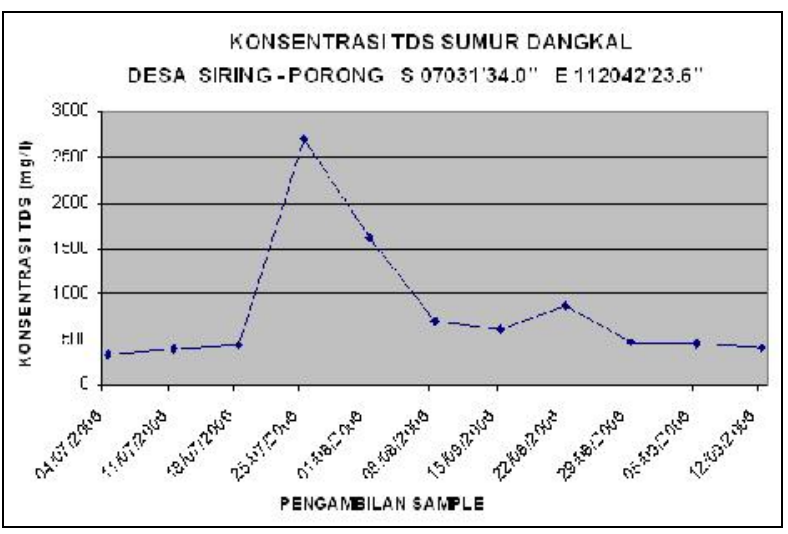

Gambar 20. Grafik Konsentrasi TDS Sumur Dangkal di Desa Siring - Porong

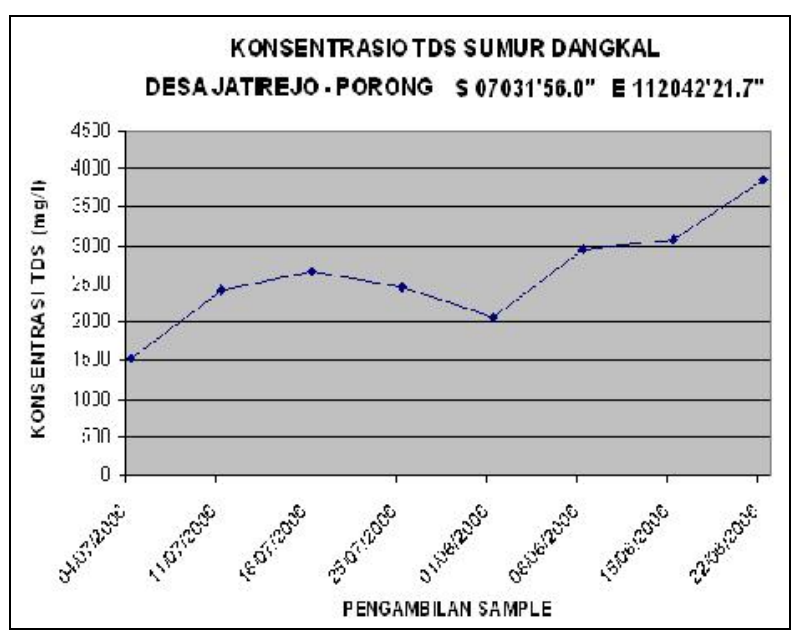

Gambar 21. Grafik Konsentrasi TDS Sumur Dangkal di Desa Jatirejo - Porong

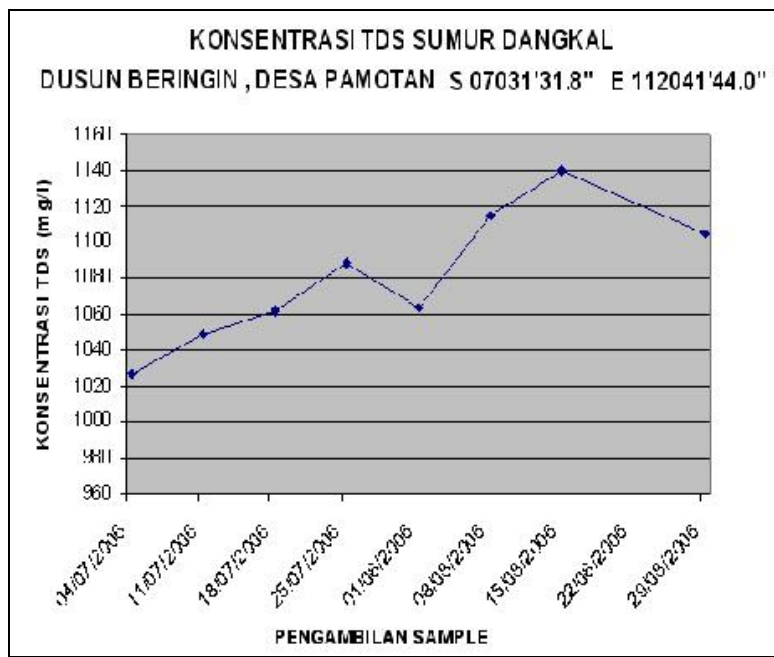

Gambar 22. Grafik Konsentrasi TDS Sumur Dangkal di Dusun Beringin, Desa Pamotan

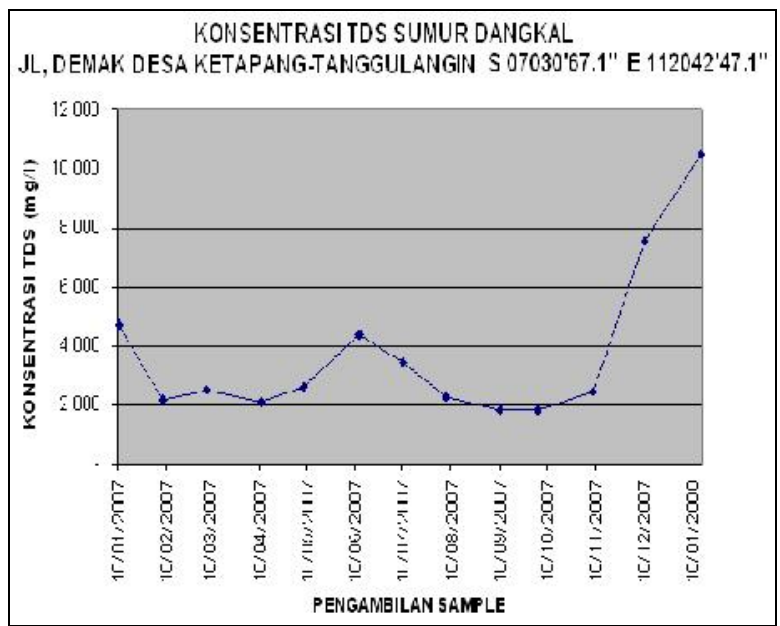

Gambar 23. Grafik Konsentrasi TDS Sumur Dangkal di Jl. Demak Desa Ketapang Tanggulangin 


\section{KESIMPULAN DAN SARAN}

\subsection{Kesimpulan}

Dari hasil kegiatan pemantauan kualitas air sumur penduduk di wilayah sekitar semburan lumpur Sidoarjo, khususnya yang berada di sebelah barat dapat disimpulkan sebagai berikut:

- Sumber air penduduk, meskipun kualitasnya bervariasi, pada umumnya memiliki kualitas air dengan kadar garam yang tinggi yang ditandai dengan TDS dan konduktivitas yang mencapai angka ribuan.

- Kualitas air sumur bor meskipun bervariasi, pada umumnya memiliki kualitas air dengan kadar garam yang tinggi yang ditandai dengan TDS yang mencapai angka ribuan.

- Air yang keluar dari sumur pompa kategori bubble besar juga pada umumnya disertai dengan debit air yang sangat besar (karena pada umumnya tipe bubble besar tersebut berkaitan dengan sumur bor tanah dalam).

- Hasil analisa kualitas air sumur dangkal yang diamati oleh BPLS yang dilakukan sejak tahun 2006 menunjukkan peningkatan nilai TDS yang artinya terjadi penurunan kualitas. Rata-data TDS adalah $<5000 \mathrm{mg} / \mathrm{l}$ walaupun di Desa Ketapang terdapat beberapa hari dengan nilai TDS > $5000 \mathrm{mg} / \mathrm{l}$ (gambar 2023).

- Peningkatan nilai TDS pada sumur dangkal dapat disebabkan pengaruh rembesan air lumpur yang masuk ke dalam akuifer tanah dangkal.

- Hasil analisa kualitas air sumur bor / sumur dalam yang telah diamati juga menunjukkan peningkatan nilai TDS walaupun tidak terlalu signifikan di atas nilai baku mutu, yakni masih di antara $700 \sim 1100 \mathrm{mg} / \mathrm{l}$. Sedangkan nilai $\mathrm{pH}$ untuk semua titik pantau masih berada di antara ambang batas baku mutu (tabel 5).

- Pemasangan separasi gas dan air sangat berguna diantaranya untuk mengurangi terjadinya bencana lain yang berhubungan dengan tingginya konsentrasi gas metan dan untuk mempermudah pengamatan kualitas air yang keluar dari sumur dalam yang umumnya keluar dengan debit yang sangat besar.

\subsection{Saran}

Pelaksanaan kegiatan pemantauan kualitas air di sekitar wilayah semburan lumpur Sidoarjo dilakukan dalam waktu yang relatif singkat dengan beberapa permasalahan yang terjadi di lapangan. Berikut ini adalah saran yang dapat diberikan terhadap pelaksanaan kegiatan pemantuan kualitas air tersebut :

- Pengoperasian multi probe sensor digital menggunakan laptop membutuhkan waktu persiapan yang cukup lama, terutama jika dilakukan secara berpindah-pindah dari satu titik lokasi ke titik lokasi yang lain. Selain itu pengoperasian sangat dipengaruhi oleh ada tidaknya sumber listrik terdekat di lokasi yang akan diamati. Oleh karena itu disarankan menggunakan handheld display dengan sumber listrik dari batere yang memang dikhususkan untuk sensor tersebut.

- Semburan air yang keluar dengan jumlah yang besar pada beberapa sumur bor kategori bubble besar sebaiknya diukur debitnya menggunakan flow meter yang mampu mengukur debit air dengan tekanan yang besar.

- Semburan air yang sangat kencang sangat menyulitkan jika tidak dibuatkan pemisah air dan gas. Oleh karena itu pengukuran kualitas air sumur bor hanya mungkin dilakukan dengan mengumpulkan air yang keluar ke dalam wadah terlebih dahulu.

- Proses perekaman data oleh sensor digital selain dilakukan secara otomatis dengan menggunakan perangkat lunak yang ada, sebaiknya dilakukan penyalinan data secara manual dari layar monitor ke dalam data sheet menggunakan MS Excel. Hal ini dilakukan untuk mencegah terjadinya kehilangan data pada saat mobilisasi peralatan sensornya.

\section{DAFTAR PUSTAKA}

1. Tim Nasional Penanggulangan Semburan Lumpur di Sidoarjo (April 2007), Ringkasan Eksekutif Laporan Akhir Penanggulangan Semburan Lumpur di Sidoarjo

2. WP Hidrologi dan Geokimia (September 2008), Brief Report : Pengukuran Konsentrasi Gasn dan Air di Wilayah Sekitar SemburanLumpur Sidoarjo

3. Heru Dwi Wahjono dan Bayu Budiman (Mei 2006), Sistem Manajemen Komunikasi Data Jarak Jauh Berbasis Teknologi SMS dan Radio Telemetri Untuk Pemantauan Kualtias Air, JTL Vol 7 No. 2 Mei 2006

4. Tim Pemantau Kualitas Air (2006), Pemantauan Kualitas Lingkungan Aspek Kualitas Sumber Daya Air di Daerah Semburan Lumpur Sidoarjo Periode Juni November 2006, Dep. PU

5. YSI Environment (2008), 6 Series Instruments and Product Quick Select Guide, www.ysi.com 


\section{LAMPIRAN}

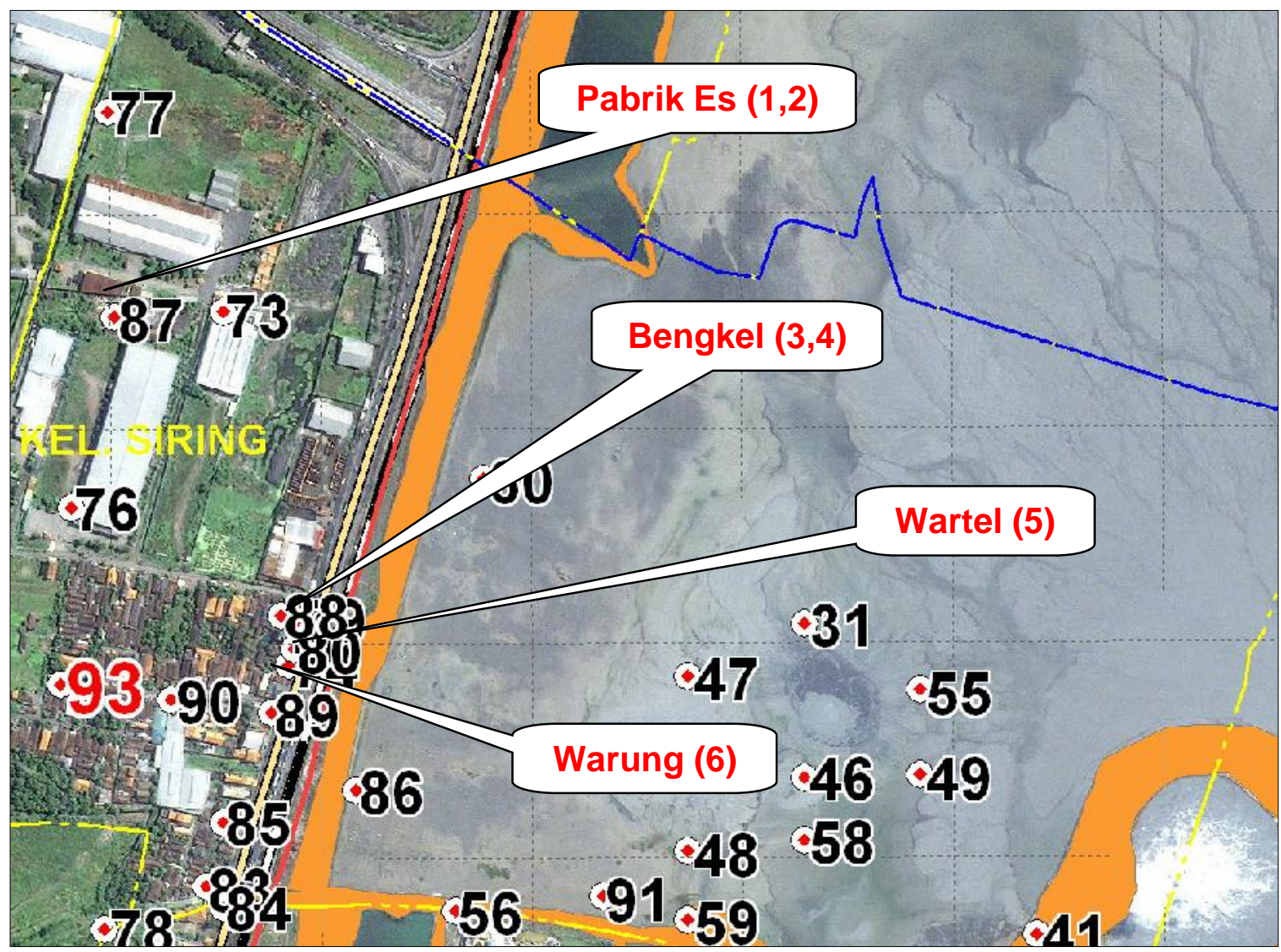

Gambar 24. Peta Lokasi Survei Kualitas Air dari Sumur Pompa Dengan Ketegori Bubble Besar di Sebelah Barat Tanggul Lumpur

Tabel 5. Kualitas Air Dari Bubble Kategori Besar Di Desa Siring Barat

\begin{tabular}{|c|c|c|c|c|}
\hline No. & LOKASI SUMUR & TDS (mg/l) & pH & KETERANGAN \\
\hline 1 & $\begin{array}{l}\text { Pabrik Es Sumur } 1 \\
7^{\circ} 31^{\prime} 21,4^{\prime \prime} \text { LS , } 112^{\circ} 42^{\prime} 8,8^{\prime \prime} \mathrm{BT}\end{array}$ & 880 & 6,03 & \multirow{2}{*}{$\begin{array}{c}\text { Baku Mutu TDS dan } \\
\text { pH Berdasarkan } \\
\text { Kelas menurut } \\
\text { PP No. } 82 \text { Tahun } \\
2001\end{array}$} \\
\hline 2 & $\begin{array}{l}\text { Pabrik Es Sumur } 2 \\
7^{\circ} 31^{\prime} 21,4^{\prime \prime} \text { LS }, 112^{\circ} 42^{\prime} 8,8^{\prime \prime} B T\end{array}$ & 930 & 7,40 & \\
\hline 3 & $\begin{array}{l}\text { Bengkel Kendaraan } \\
7^{\circ} 31^{\prime} 30,8^{\prime \prime} \text { LS , } 112^{\circ} 42^{\prime} 13,3^{\prime \prime} \text { BT }\end{array}$ & 1020 & 5,8 & Tentang \\
\hline 4 & $\begin{array}{l}\text { Bengkel Kendaraan } \\
7^{\circ} 31^{\prime} 30,8^{\prime \prime} L S, 112^{\circ} 42^{\prime} 13,3^{\prime \prime} \mathrm{BT}\end{array}$ & 800 & 5,9 & $\begin{array}{l}\text { Kualitas Air Dan } \\
\text { Pengendalian } \\
\text { Pencemaran Air }\end{array}$ \\
\hline 5 & $\begin{array}{l}\text { Wartel } \\
7^{\circ} 31^{\prime} 33,9^{\prime \prime} \text { LS , } 112^{\circ} 42^{\prime} 58,9 \text { " BT }\end{array}$ & 5040 & 5,8 & $\begin{array}{c}\text { TDS : } 1000 \mathrm{mg} / \mathrm{l} \\
\text { (untuk semua kelas) }\end{array}$ \\
\hline 6 & $\begin{array}{l}\text { Warung Ibu Purwaningsih } \\
7^{\circ} 31^{\prime} 33,3^{\prime \prime} \text { LS , } 112^{\circ} 42^{\prime} 11,8^{\prime \prime} \text { BT }\end{array}$ & 760 & 6,24 & $\begin{array}{c}\mathrm{Ph}: \text { 6-9 } \\
\text { (untuk semua kelas) }\end{array}$ \\
\hline
\end{tabular}




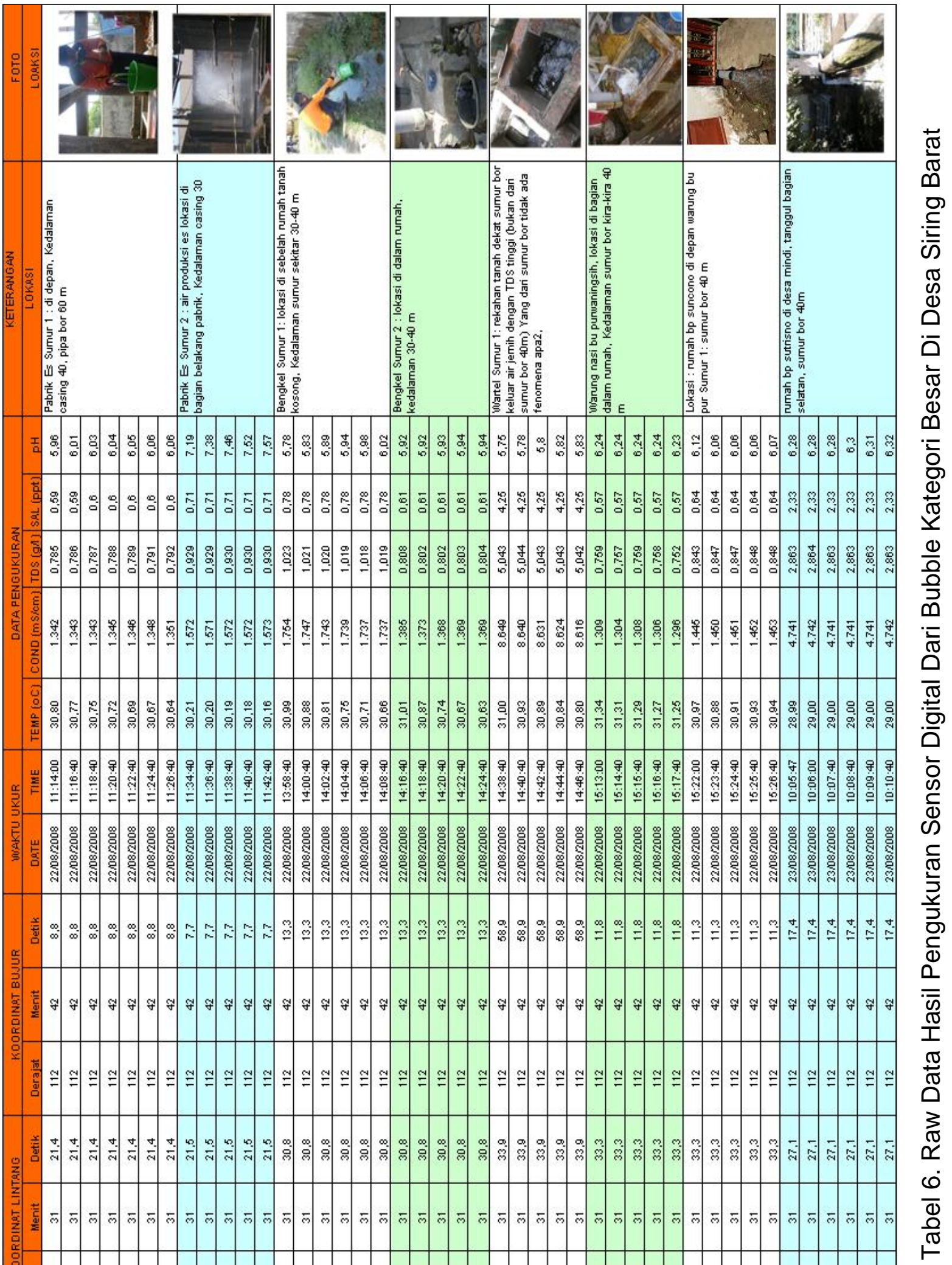




\begin{abstract}
Abstrak
Semburan lumpur di Sidoarjo telah menimbulkan perubahan kualitas lingkungan di sekitar wilayah semburan. Pengamatan di lapangan menunjukan telah terjadi perubahan kualitas udara dan bau yang diakibatkan semburan lumpur tersebut. Selain itu perubahan struktur geologi di dalam tanah di wilayah sekitar semburan lumpur telah mengakibatkan fenomena munculnya semburan-semburan air yang berasal dari sumur pompa di beberapa rumah penduduk di wilayah tersebut. Fenomena tersebut diikuti dengan terjadinya perubahan kualitas air yang tadinya dapat digunakan untuk keperluan hidup sehari-hari, kini di beberapa desa di sekitar wilayah semburan lumpur tidak dapat lagi digunakan. Untuk mengetahui beberapa parameter kualitas air yang muncul dari sumursumur yang menghasilkan semburan yang cukup besar perlu dilakukan pemantauan kualitas air dengan menggunakan sensor kualitas air yang mampu mengukur beberapa parameter sekaligus. Tulisan ini menyajikan data pengukuran kualtias air di beberapa sumur penduduk yang menghasilkan semburan air cukup besar dengan menggunakan sensor YSI600R.
\end{abstract}

\begin{abstract}
Bursts of mud in Sidoarjo has caused changes in environmental quality around the bursts area. Observation in that area indicate there have been changes in air quality and odor caused by mud spurt. In addition, changes in the geological structure of land in the area around the mud spurt, has resulted some water spurt phenomenon that came from the well pump belong to some residensts in that area. This water spurt phenomenon is followed by the change of water quality which was to be used for the needs of daily living, now in some villages in the area around the mud bursts can no longer be used. To find out some parameters of water quality that arises from the some well pumps that produce big water spurt, we need to performed water quality monitoring using multiprobe digital sensors that are able to measure several parameters at once.This paper presents the measurement data of water quality in some well pumps that produce big water spurts with the YSI600R digital sensor.
\end{abstract}

